\title{
毛利藩における宮市宿本陣兄部家について HON-JIN AT MIYAICHI STAGE IN MOURI-HAN DURING EDO ERA
}

\author{
岡田悟* \\ Satoru OKADA
}

\begin{abstract}
Hon-jin was a lodging used by feudal lords in Edo era. Miyaichi was a stage of both Sanyou Road and Hagi Road in Mouri-han and Koube managed the hon-jin. While a lord was staying at hon-jin, the main part of hon-jin building was occupied as a dwelling of a lord and followers and cookroom. The spare house that Koube family could use while a lord was staying was not prepared. Lords entered this hon$j$ in by way of the garden in front of the main room, Gozama. So, Genkan was not used as an entrance of lords.
\end{abstract}

Keyvords:Hon-jin, lords, lodging, Mouri-han, Miyaichi 本陣，大名，休泊施設，毛利藩，宮市

\section{1.はじめに}

毛利藩内に設けられた藩主休泊用の施設の概要につい ては、前稿 (*注 1) で触れ、そうした施設の例として 三田尻御茶屋を対象に、その建築実態、歴史的変遷を明 らかにした。一方、毛利藩内を山陽道が通過し、その宿 駅には参勤交代をする九州の諸大名等が休泊に利用する 施設すまた必要とされた。今回採り上げる宮市宿は、 『防長風土注進案』（以降注進案と略称する）に「九州 往還にて御大名様方其外御休泊之宿驛」とあるように山 陽道の宿駅であった。同時に、城下町萩から山口を経て 三田尻御船倉を結ぶ萩往還（毛利藩主参勤路）むまたこ の宮市を通っていた。この状況を注進案絵図（図2）に よってうかがうと、宮市町は東西に走る山陽道に沿って 東から前小路、中市、新町、今市によって構成され、北 には防府天満宮が控え、その門前町としての性格も兼ね 備えていた。一方、萩往還（図2 では山口街道と記され ている）は北西から鯖川（佐波川）を渡り町の西端で山 陽道に合流し、東進して天満宮前で右折し三田尻へ向か
っている。従って、宮市町の内、今市、新町、中市の区 間は山陽道と萩往還が重複していることになる。 注進案には中市に御本陣として兄部盤右衛門が、新町 に脇本陣として中村善左衛門および市川五郎左衛門の 2 軒が記されている。本陣兄部家には藩政期の建築が遺さ れていて、史跡に指定され、同家に伝えられる文書を中 心とした調查結果が発表されている（文献２）。しかし、 詳細な建築史的な調查は行われず、建筑年代も不明なま まであり、修理工事報告書（文献 $7 \sim 9$ ）、学会発表 （文献14）、著書（文献11～13）等の、関連する数多く の研究成果と照らし合わせて検討することが不可能であ った。

兄部家は現在 J R 山陽線防府駅北方約 $1 \mathrm{k} \mathrm{m}$ 程の所に あり、前述の三田尻御茶屋遺構とは、防府駅を中心とす る市街地の中に、共に取り込まれている（図1）。しか し、藩政期には、図 2 に描かれるように宮市と三田尻は 間に田園地帯を挟む別の集落であった。性格も、御船倉、 勘場、御茶屋等の藩施設を中心とする港湾行政都市であ

* 共立女子短期大学生活科学科 講師·工博

Lecturer, Dept. of the Science of Living, Kyoritsu Women's Junior College, Dr. Eng. 


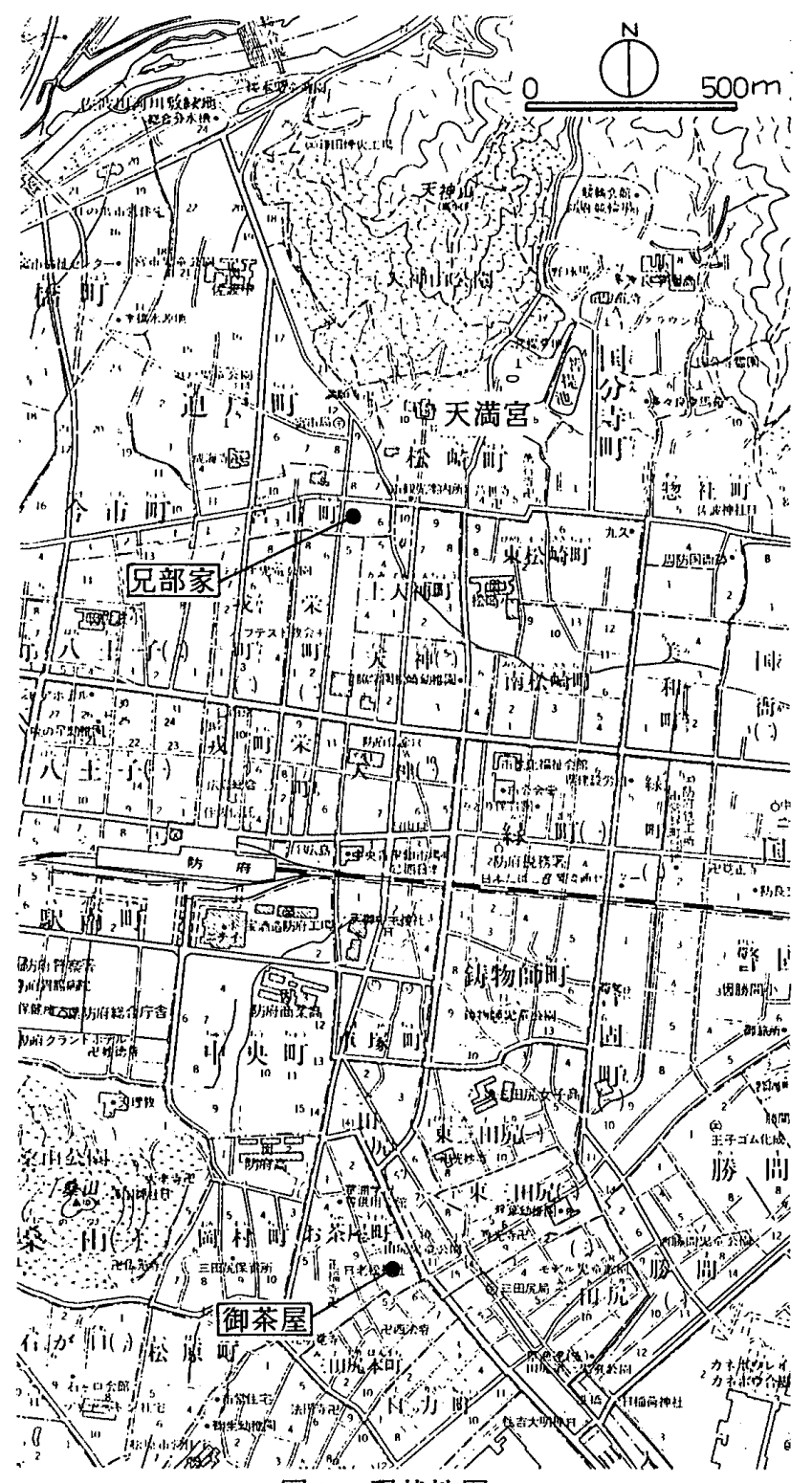

図 1 現状地図

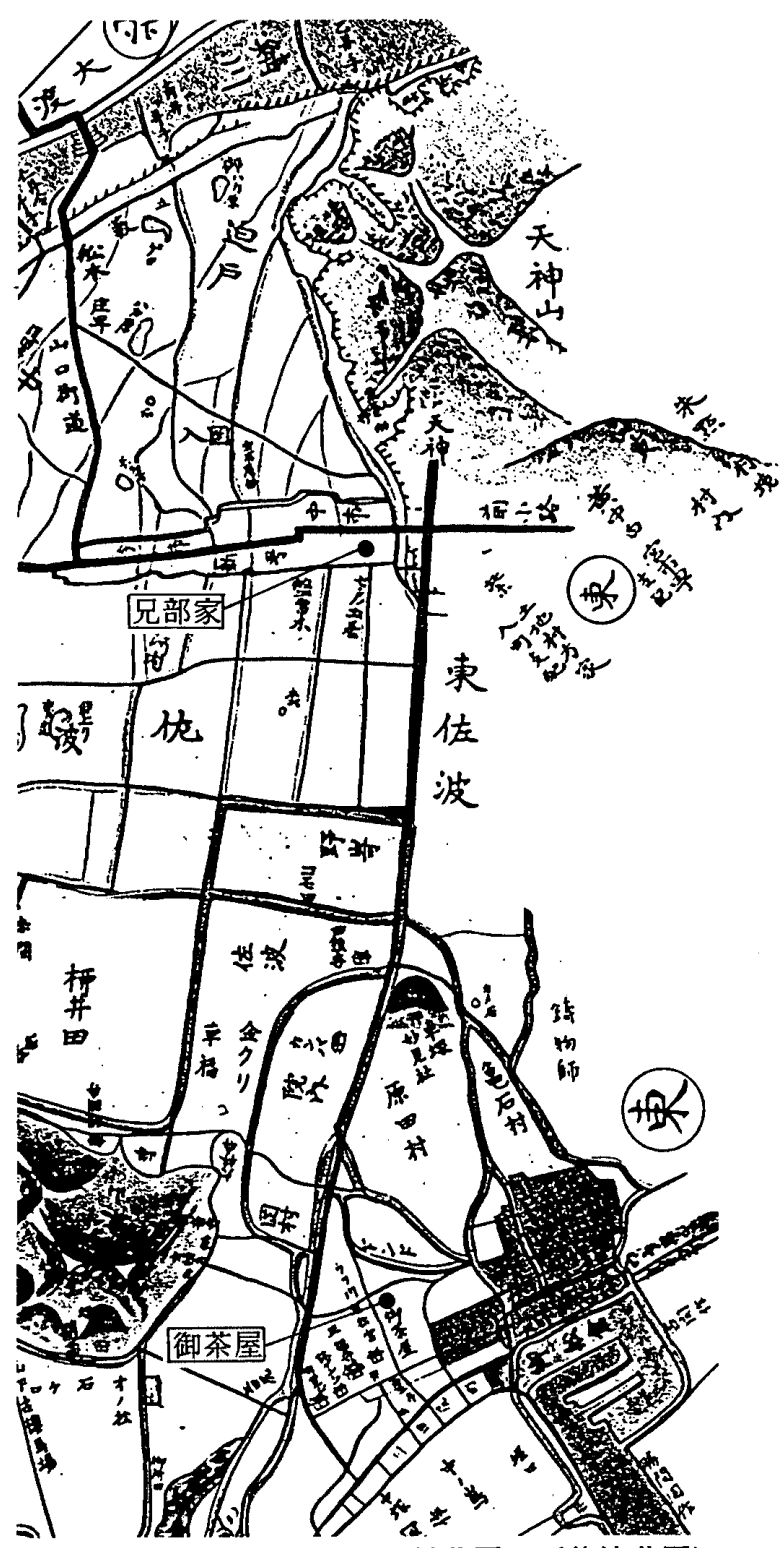

図 2 注進案絵図（三田尻村荒図＋西佐波荒図）

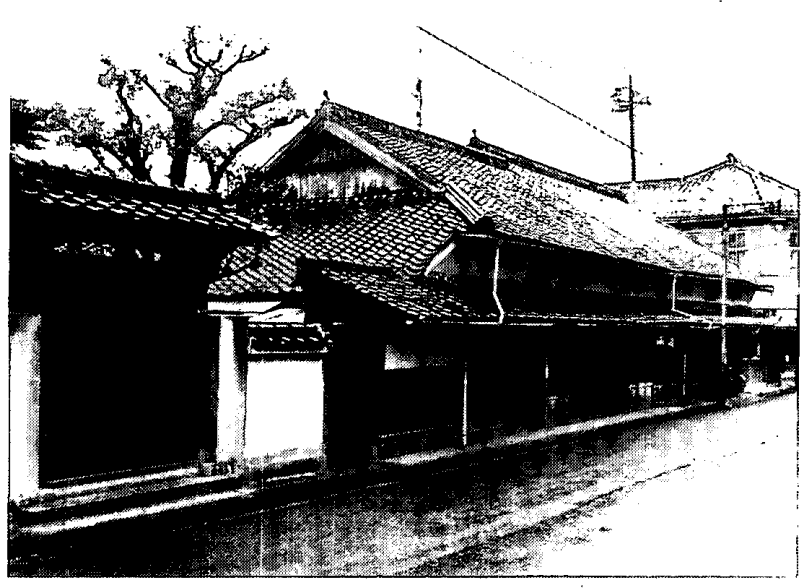

写真 1 兄部家主棟西側部分（北側街道面）

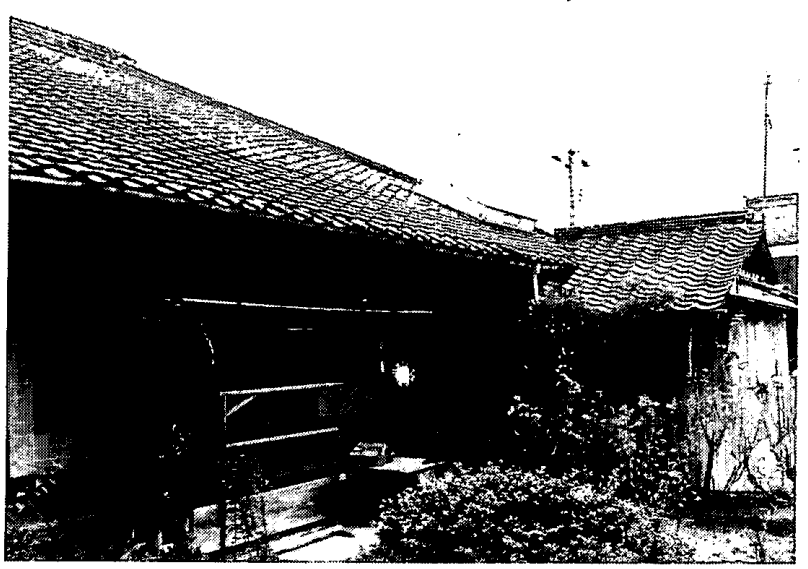

写真 2 兄部家主棟東側部分（南側） 
った三田尻に対し、本陣、2 軒の脇本陣、天満宮等を中 心とする宿駅門前町であった宮市と、異なっていた。し かも、以下に述べるように、三田尻御茶屋に建てられて いた建物を兄部家へ移築した、という記述が見られ、こ れの確認も未だなされていなかった。

以上の状況を基に、本稿では、まず、兄部家遺構の現 状を報告し、次に、絵図や文献、おょび、前稿で得られ た三田尻御茶屋に関する知見を基に建築年代ならびに移 築の真偽を明らかにし、更に、休泊時における諸部分の 使われ方の検討を通して、兄部家の本陣としての建築的 特徴を考察してみたい。

\section{2 . 兄部家の現状}

兄部家は山陽道の南側に位置し、天満宮入口から西へ $150 \mathrm{~m}$ 程の所にある。敷地北側が旧山陽道に面する他、 西側む横丁に面している。現状配置図（図 3）加ら、街 道に面して建つ、東側入母屋西側切妻栈瓦莫の本家（写 真 1) と、街道加ら奥まって建つ、寄棟栈瓦萁の害院 （写真 2) とが連結される形で主たる棟が形成されてい ることが知られる。寄棟屋根には、棟両端、および、隅 棟端 4 力所のうち 2 力所の計 4 力所の鬼瓦に、毛利家家 紋である長門三ッ星が付せられている。書院の南北には 庭園がしつらえられ、北側庭入口には街道に面して瓦草 袖塀付き棟門が設けられている。この門は昭和46年に台 風によって破損した門を同じ位置に建て替えたものであ る(*注 2 ) 。これに対し、西側部分の背後には本蔵、 道具蔵の他、多くの付属屋が建ち亚び、東側とは様相を 異にしている。

次いで、現状平面図（図4）を見ると、書院は北側に 入側を備えた 2 列 6 室を中心とし、床の間や内雨戸の縁 む含めて、よく旧状を遺している。この座敨部分の東に 台所、浴室、便所等が付属し、現在住宅として使用され ている。一方、本家は通り土間を遺すものの他は改変さ れ車庫、店舗等に用いられている。東端 1 間半を除いて つし二階が設けられているが、現在は使用されていない。 東側が書院造りの、そして、西側が町屋型民家の平面構 成の特徴を示していることが知られ、これに対応して架 構の状況も差鴨居の用い方等の点で両部分に差異が認め られる。

\section{3. 兄部家の建策の変㘪}

注進案によって兄部家の歴史を眺めると、鎌倉時代よ り「周防國合物商賣人等長職」を勤的、室町時代には 「天満宮社役所勤」とあり、当地方きっての有力商家の 家柄である。武士の休泊に関しては、「元和年中ょり上 使御客屋と申名目二而、寛永拾九年よりは御大名様方御
本陣二被仰付罷在候」とある。一方、同家の『累代遺語 抜卒』には「同記（与右衛門宗知君往事記）二日ク、我 ガ家御大名醇，御旅館トナリシ由来八、寛永九年長崎肥 前豊前等工御上使始テ陸地往来入時.......当駅八祖父与右 衛門直季、御馳走トシテ御旅館 $习$ 造営セリ、又䙾文三年 巡見ノ御上使往来ノ時、父与右衛門直久復ビ修復 $\exists$ 加工 御馳走セリ、此後遂二御大名衆ノ御旅館トハナレリ」

（*注 3）とあり、注進案の内容と異なっている。注進 案は幕末の、また、『累代遺語拔萃』は明治初年の編策 であることから、藩政初期の事柄については共に信頼性 に問題が残るところであるが、おおむね 1600 年代中頃に は武士休泊の機能を果たしていたと考えてよかろう。 「上使御客屋」「御本陣」「御旅館」等と記される建物 の実態は不明なものの、有力商家としての大規模な敷地、 建物によってかかる機能を果たし得ていたと予想される。 薩摩藩主島津氏宿札が遺されているように、参勤交代時 の休泊に利用されたが、毛利藩主も藩内巡視時に天満宮 祭礼見物を兼るて、兄部家を利用するなどしていた（） 注 4) 。この他、家業としての酒造業は、元和年間には 始められていた（*注 5 )。

その後、寛政元年（1789）4月13日「周防国宮市町出 火家数百廿戸焼亡」（文献 4）と大火があり、この時兄 部家も注進案に「寛政元酉ノ四月家宅類焼」とある如く 焼失したが、続いて「三田尻御殿之内買洋領被仰付」と ある。「三田尻御殿」は三田尻御茶屋を指し（*注 1 ）、 「之内」とあるところからその一部を「買拝領」即ち代 金を払って譲り受けたということになるう。この頃の三 田尻御茶屋は、天明 3 年より側室や娘と共に居住してい た 7 代藩主重就（天明 2 年に隠居）が寛政元年10月 7 日 に死去し、それに伴って建物規模が大幅に縮小された時 期に当り（*注 1)、従って、余剩の建物の払い下げは 十分あり得ることである。

一方『累代遺語抜萃』には、この䙾政元年焼失後の再 建について「右田御屋数ヨリ従来ノ御由緒アルョ以テ彼 ノ城山ノ材木 7 数多睗りタルニ由リ、他二先立ッテ本屋

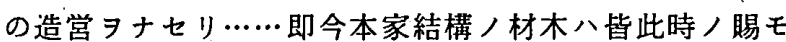
ノナリ」とある（*注6）。右田御屋敷とは「右田御屋 敷八当時毛利大内蔵卜称セシ由ナリ」（*注 6 ）とある 如く藩主毛利氏と姻成関係にあり右田の在郷屋敖を中心 に 1 万 6 千石余を知行していた家老右田毛利氏を指し、 城山とは右田村内に古城跡と伝えられる山を指す（*注 7 ）。ここに示される右田毛利氏からの材木で建築した とする記述は注進案のそ扎と異なっており、この点の解 明も必要となる。

藩政期における兄部家の建築実態を知り得る資料とし ては、

(1)同家所蔵の「宮市驛御本陣兄部盤右衛門処差図」（天 保11年、図 5 ) 
(2)山口県文書館毛利文庫の「兄部三蔵家差図」（図6) (3)注進案の「御本陣壹ヶ所 兄部盤右衛門」の記述（天 保13年〜弘化)

が挙げられる。図4、5、6を比較すれば、主棟に関す る限り、基本的にこれら 3 種の図面は同一の建物を描い たものであることが容易に理解される。

注進案には兄部家が、本門、本家、書院、火除門、酒 造蔵、同絋酒造蔵、裹門の 7 部分に分けて記されている。 本門は図 $5 、 6 に$ 書き込まれ、台風で壊れた後もその 位置は現在（図3）に受け継がれている。本家は「五間 半梁桁行五間半、北入半間長五間半之錣、南入壹間長四 間蒀下ヶ……本棟より東江五間梁二桁行四間、北入半間 長四間之錣、東ノ方入壹間半長五間半直下ヶ……屋根惣 瓦荤之事」とあり、寸法、屋根形状等加ら主棟の西半分 と判断される。現在間取りは大きく改変されているが図 6 に描かれる主要な柱は現在むほとんどそのまま遗され、 また、部屋境の鴨居も旧来の位置に遺り、図6の間取り に復元される。通り土間す、天井仕上げや鴨居の状況か ら 1 間半幅に復元される。書院は「四間半梁、尤外共二 五間半、桁行五間半外ともに六間半、東ノ隅壹間梁長武 間之注文御湯殿、屋根瓦惪之事」とあり、桁行が図 5 、 6 の 7 間半、図 4 の 8 間と相違するすのの、主棟の東半 分に該当しよう。架出部である中門（注文）については、 その位置、寸法、用途は図 6 に一致し、また現状からす、 屋根形状（図3）邖「壹間梁」を西に半間分下げおろし たものと思われ、図 6 に「口」とある部分に庇の腕木の 古い材が遺され、かっては風呂場であったと伝えられ (*注 2 )、図6の状況に復元される。火除門、裹門は 共に図 5 に書き込まれている。

酒造蔵は「三間梁二桁行拾三間半……中程注文壹棟壹 間梁二析行三間室場之分」、同續酒造蔵は「三間梁二桁 行五間」とある。これを図 5 と比較すると、「酒蔵」と ある細長い付属屋が両者を合わせて描かれたあのと思わ れるが、中程にあるとされる中門が描かれていない。一 方、図 6 と比較すると、酒造蔵が「三間梁二拾四間」 (図では 9 間半) の「蔵」として描かれ、梁行が 2 間で あるすのの桁行 3 間の「蔵」が「中程注文」に相応しく 描かれているが、同續酒造蔵があると思われる場所は紙 をはずれている。現状（図 3 ）の道具蔵が古い酒造蔵の 一部と伝えられる（*注 2) が詳細は不明である。その 他の付属屋は現存しない。

さらに、本家の項に記される突出部分をみると、「南 八隅ちうむん畿間四方、南ちうもん武間半梁二桁行五間、 ちうもん南端より東江注文武間梁桁行壹間半」とある。 最初の 2 間四方のあのは図 6 で西側の、次の 2 間半 $\times 5$ 間は東側の「釜屋」にそれぞれあてはまり、これらは共 に図 5 にむ描かれている。しかし、最後の 2 間 $\times 1$ 間半 は図 5 には描かれているが、図6には欠落している。こ
れらも、現在は建て替えられている。

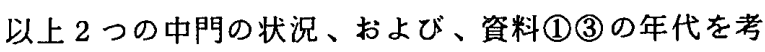
虑すれば、まず天保11年に図 5 の状態であったすのに、 酒造蔵中程に室場として中門が付せられた後、注進案に 記録され、更にその後、本屋後部の中門が取り去られて 図6の姿となった、とするのが妥当であろう（*注 8）。 敷地奥行寸法は注進案には記されてなく、図 5 の状態の 後、図 6 では奥行が縮小されたのか、あるいは、同續酒 造蔵部分を略したのか、不詳である。

従って、現状の主棟は天保11年以前より基本的な部分 を受け継き、後部の乫出部、道具蔵を除く付属屋は天保 13年を遡ることはない、と言うことが出来る。しかし、 寛政元年の焼失後の再建経緯と、天保11年の絵図に示さ れる建物との関係は、未だ明確になっていない。

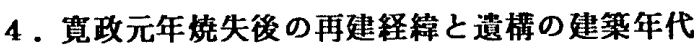

天明年間に重就らが居住していた状態の三田尻御茶屋 絵図、および、注進案の内容に基づく同復元図が明らか にされている（＊注1）ので、前者に描かれ後者に描か れていない建物の中に、天保11年以後の兄部家と共通す るむのが発見されれば、それは寛政元年の焼失後三田尻 御茶屋より移築されたすのと判断されることになる。可 能性のある建物の中で、重就の側室留楚、同千佐、娘雅

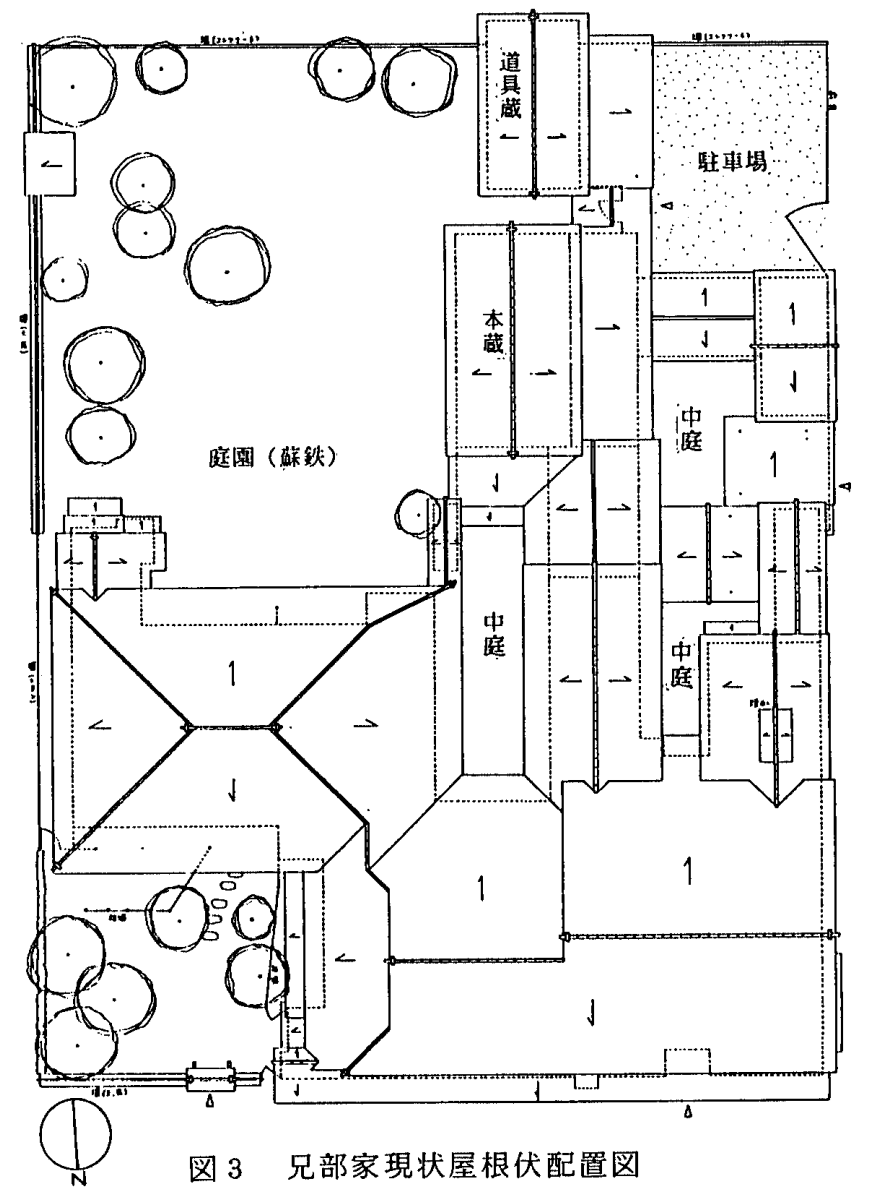




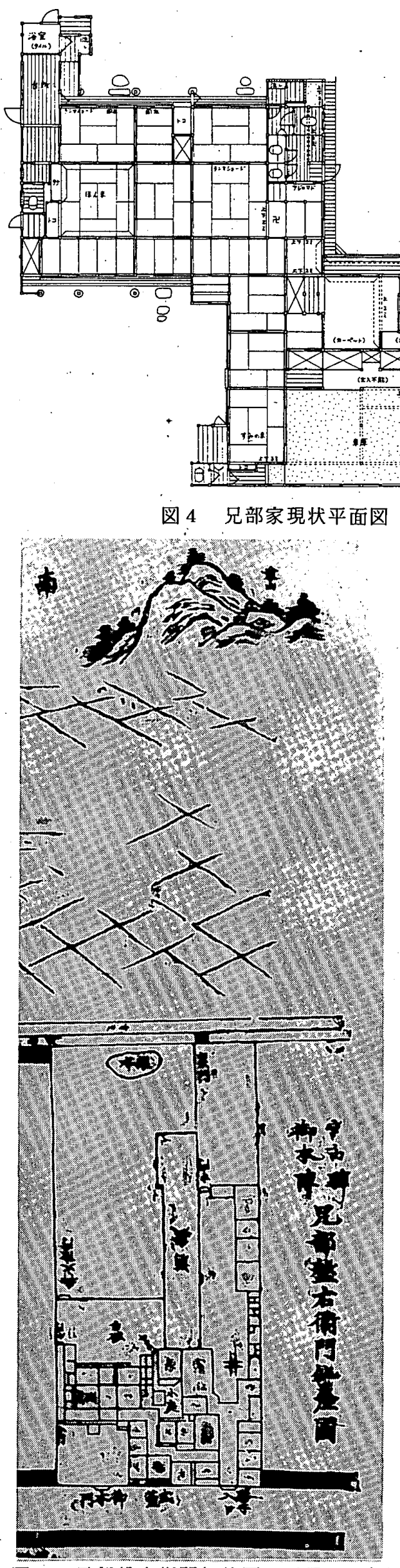

図 5 兄部盤右衛門処差図（天保１１年）

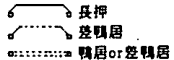

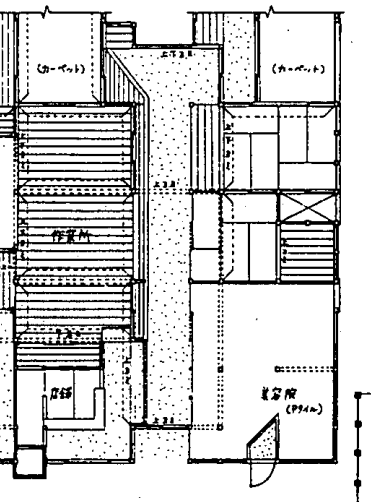

${ }^{14}$

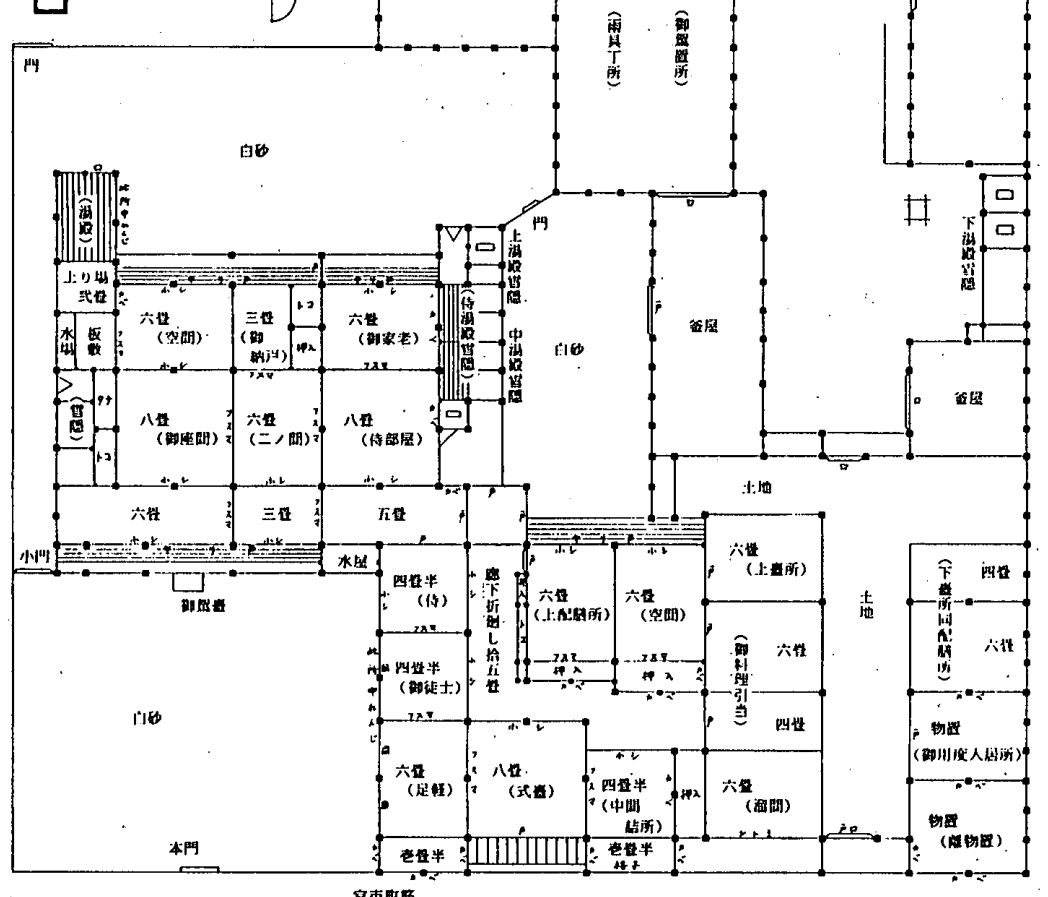

図 6 兄部三蔵家差図

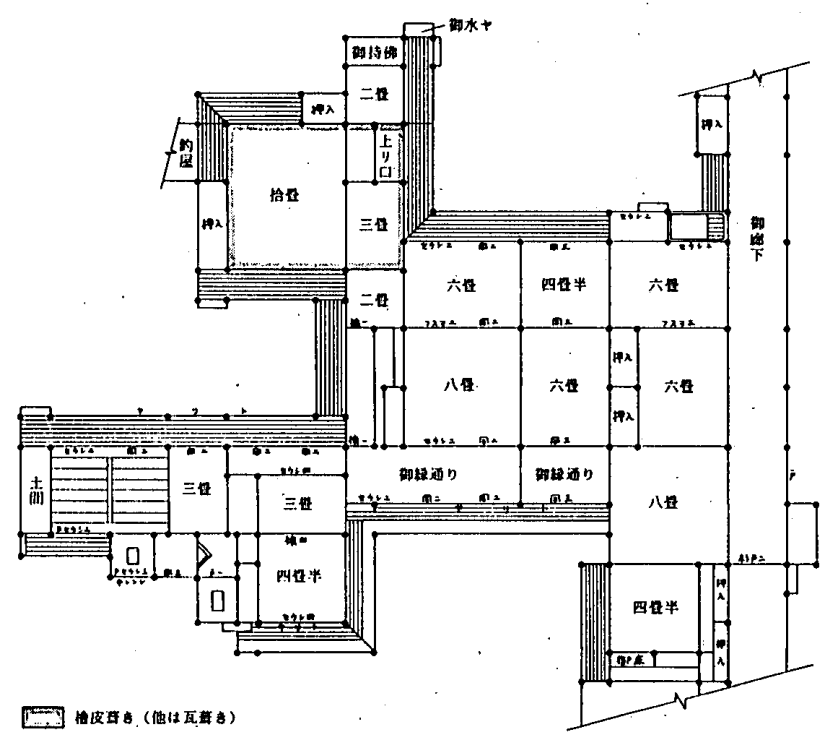

図 7 三田尻御茶屋御住居之差図 (部分). 
子が居住に用いていたと考えられる 3 棟の内の最も南に 位置する 1 棟（図 7 ）の間取りが、図4 6の害院棟に 酷似している。

即ち、図 7 で最す格式の高い部屋は「御縁通り」とあ る入側を伴う 8 畳間と考えられる（*注 9$)$ が、これは 現状（図4）で唯一長押の迴されている「ほんま」に当 り、床の間や棚の現状は図 7 に一致する。他の 5 室す、 押入等の撤去や後補はあるものの、そのまま受け継がれ、 入側や緑の状況も一致する。建具についても、図 7、6、 4 を比べると、図 7 の上側外壁部分が外雨戸であるのに 対し図6、4で内雨戸となっている他は、矛盾しない。 図 7 で檜皮惪きと表現される 10 盢（「御納戸」と推定 される）の一面は、2 階建て（*注10）で屋根材も異な り、また兄部家敖地にも納まらず、移筑されなかったと 思われ、代わりに宿泊時に必要な湯殿が新たに付加され ている。図7の「御廊下」は 1 間幅と読み取れ、こ机は 図 6 でやはり 1 間幅の「侍湯殿雪隠」に相当しょうが、 この部分は図 6 の状態の後、半間西へ増筑されて見在に 至ったすので、柱割（図4) の他鴨居（図4) や屋根隅 棟（図 3 ）の納まりが不自然である（*注11）。

図 7 に描加机棟は、安永 5 年 天明 3 年に建築され たと考えられる (*注 1$)$ )が、これと同時に建築され現 在む三田尻御茶屋遺構の一部として遗されている、重就 の御座間であった部屋（*注 1$)$ と柱間寸法を比較する と、共に 6 尺 5 寸であり、同時に建設されたすのと考え て矛盾しない。

以上より、東側害院部分は、三田尻御茶屋内に重就の 側室留楚、同千佐、娘雅子のいずれかの居住空間として 安永 5 年〜天明 3 年に建てられた棟の主要部分を、寛政 元年の宮市町大火、重就死去の後、基本的な間取りを変 更することなく移筑したものであると言うことが出来、 姫君の御殿であったものを移築した、という伝承（*注 2)を裹付けている。

残る西側部分は、兄部家の生活や生業が営まれていた 空間であり、書院部分より先に再建が必要となる。従っ て、この部分は注進案にも記されるように「本家」であ り、「他二先立ッテ」建設されたと思われ、古材転用の 跡もなく、『累代遺語抜萃』に言う右田毛利家より睗っ た材木で建筑された部分に該当しょう（*注12）。

\section{5. 平面構成、使われ方の特就}

注進案に本家、害院と記されるように、兄部家の主た る棟付專ら武士休泊時にのみ用いられる書院部分と、兄 部家の日常的な生活に用いられる本家部分から構成され ていた。従って、武士休泊に利用されない時は本家とそ の後側の付属屋とで兄部家の生活、酒造業としての生産 が行われていた。武士休泊利用時はどうであったか、に
ついては、図6には「六畳」「蔵」といった広さや形を 示す当初よりの書き込みに加えて「御座間」「御家老」 「御徒士」「上臺所」といった䀡紙が付され、また、 「宮市御泊御本陣兄部三蔵所差図」と付記され、このよ うな宿泊利用時の各部分の使われ方を示した図であると 考えられる。では、誰がいつ利用した折の状況を描いた あのか、が問題になるが、毛利文庫に数多く遺されてい る御茶屋、本陣の絵図はほとんどが藩主の藩内巡視の記 録と対杺するすので、希に幕府よりの巡見使等が利用し た場合にはその旨が記されている(*注13)こと、兄部家 には藩主が休泊に利用してきた経緯があり、絵図の推定 年代である注進案以後の時代にも藩主が利用した事実が ある（*注14）こと等から推して、毛利藩主が宿泊に利 用した時のものと考えて䛊りなかろう。

図 6 の貼紙を検討すると、兄部家の主たる棟は

（1）「御納戸」「空間」を伴い「湯殿」「雪隠」を備 えた藩主居所としての「御座間」「二之間」

（2）「御家老」加ら「侍部屋」「侍」「御徒士」「足 軽」そして「式臺」を挟んで「中間詰所」「溜間」まで L 字型に並ぶ展従する家士の詰所

（3）裏手から通り土間両倒に配置されている「上配瞨 所」「上臺所」「御料理引当」「御用度人居所」等の台 所部分

の3 部分によって構成されれていたことが知られる。こ れは三田尻御茶屋において藩政期を通じて設けられてい た 3 部分と一致し、利用する建物の性格、規模等によら ず藩主休泊時に必ず必要となる構成要素であると考えら れる。御座間部分は床、棚、入側を備えた 2 室以上の構 成であり、また、式瞢が詰所部分にあり、一般の武士住 宅や三田层御茶屋に共通する。入側は「廊下折迴し」に 結ばれ、台所部分に連絡されていて、休泊時の食事サー ビス等の状況がうかがえる。と同時に、廊下は詰所部分 と台所部分とを区画する位置にある。裹の酒造蔵内には 「御駕置所」とあり、藩主の駕籠の置き場に用いられた。

こうして見ると、酒造蔵の一部まで及ぶ兄部家建物の ほとんどすべての部分が休泊者、扈従者の居所、あるい は、食事等のサービス用の空間に占められ、兄部家の家 族、使用人等の生活や生業の場として使える空間は残さ れていないに等しい。これらの人々がどこで何をしてい たか、が疑問となるが、直接これに答える資料は遗され ていない。

図6 のように兄部家が休泊に利用された時、家族や家 人が一時的に生活の場として使うことが出来るような別 の建物が兄部家敷地内、あるいは、近隣に用意されてい た形跡はなく、従って、図6に示される利用時には、他 の家へ移るか、あるいは、本来炊事等が出来るような備 えを欠く、つし二階か裹手の付属屋に引き籠むっていた と推測される。 
最後に、街道から兄部家に出入りするための動線を見 ると、東側より街道沿いに「本門」「式臺」「戸口」の 3 籄所の出入口が認められ、これらは図 5 にも描かれ、 それぞれ先に挙げた 3 部分に対応している。即ち、「本 門」を入ると「白砂」とある庭を経て御座間入側に設け られた「御駕臺」に達する。この動線は三田尻御茶屋に は見られなかったものである。「式臺」は本家棟の家士 詰所部分にあり、「戸口」は台所部分である通り土間へ の入口である。この両者は三田尻御茶屋にあ見られたが、 兄部家に見られるような街路に直接面する形式のすので はなかった。藩主が兄部家に出入りした時の動線を示す 記録はないが、呼称から推して「本門」から入り、「御 駕臺」に駕籠が付けられたと考えられる。また、図6に おいてこの「御駕臺」は貼紙ではなく当初よりの書き込 みであり、図 5 にあ描かれていることから、臨時的なも のというょり、むしろ恒久的なあのであったと言えよう。

\section{6. 轺び}

以上の検討から次の 4 点が指摘される。

[1 $]$ 現兄部家遺構は寛政元年の燒失後の再建で、東側 書院部分之西側本家部分からなる。まず、本家が毛利右 田家よりの材木で建築され、次いで、安永 5 年〜天明 3 年に三田尻御茶屋内に留楚、千佐、雅子のいずれかの居 住用に建てられた棟が書院部分として移筑された。

[2] 参勤交代時の他藩大名にも、藩内巡視時の毛利藩 主にも利用され、藩主休泊時の状況を示すと推定される 絵図によれば、その機能を果たすため藩主の居住部分、 扈従する家士の詰所部分、台所部分の 3 部分が兄部家主 棟内に設けられた。

[ 3 ] 上記の利用例では兄部家主棟の大部分が上記 3 部 分によって占められたが、これとは別に家族や家人が独 立して生活を営むための建築的な用意はなされていなか った。

[4]街道に直接面する形で式台が設けられていたが、 藩主はここから建物に入るのではなく、棟門＼cjkstart庭＼cjkstart御座 間入側に設けられた駕籠台という動線で入ったと考えら れる。

以上は毛利藩主が利用したと推定される事例を対象と した、主に毛利藩内の資料に基づく結論であり、さらに、 通過する他藩大名の利用時等の検討が必要となろう。ま た、［3］［4] に示される建築的特徽は、従来研究が 進んで広く知られていた東海道の本陣（*注15）と大き く異なり、山陽道の本陣遗構 (* *注16) と異なる一方、 毛利藩内（*注17）や他の地方（*注18）の武士休泊施 設には散見されている。従って、兄部家におけるこうし た特徵が、例えば、本来別の性格の建物を移筑した、と いうような個別的な理由によるものか、毛利藩内の本陣
に特有のものであるのか、あるいは、むしろ藩単位の特 徵として毛利藩内の武士休泊施設全体に認められる特徴 であるのか、さらには、より広範囲な全国レベルでの特 徵の分布が認められてこれと関連するのか、と言った問 題が次の課題として生じてこよう。これらの点について は、さらに多くの例をふまえて検討を試みたい。

\section{謝辞}

本稿をまとめるに当り、実测調查に関して兄部次郎氏、 おょび、防府市教育委員会原田勝美氏の協力を得た。付 記して謝意を表したい。

注

1) 拙稿「毛利潘における三田尻御茶屋について」(『日本建築 学会計画系論文報告集』444,pp. 127～137, 1993.2）

2) 兄部次郎氏嘉

3) 文献 2 pp. 15

4 ) 明和 3 年(1766)の『山口宮市小郡御越之記』（山口県文害館 蔵) に7 代藩主重就の行野として「九半時宮市御着……御本陣 兄部所被極御宿候間」とある。これは文献 3 pp.101にも同年の 記事として「當祭礼之節、重就并澄姫御姫様（重就六女）、御 艮屋様（澄姫実母饭田利尾）富所為御步行被遊御越候、中市兄 部勘右衛門御本随相成候事」と曹加れている。

5 ) 文献 2 pp. 8

6 ) 文献 2 pp. 23

7 ）『防長地下上申』（山口県文害館荿）の石田村夆出（寛延 2 年）に「古城跡と申伝候……城山共申来候」とある「镜音堂南 之峰」が記されている。

8 ) 図 6 に示される「三葴」を名乗ったのは文献 2 pp.2の兄部家 系図中、文政 9 年(1826)に死亡した24代佳忠とされ、注進案以 降とする推定に矛盾するが、同系図で三蔵とはされていない23 代盛長洔代の寛政 3 年 (1791) 5 .月の記事として文献 6 に「三田 尻才（宰）判宮市本随兄部三蔵居宅去々酉年致焼失候……」と あり、代ヶ兄部家当主は三蔵と呼ばれていたと考えられる。

9）「三田尻御茶屋御住居之差図」（注1の図3）には、留楚、 千佐、雅子の居住用の 3 棟が描かれ、いずれも平面はよく似て いるが、この内図 7 に示した以外の 2 棟には、この 8 量間に相 当する部屋に「御居間」と書き込まれている。

10）「三田尻御住居差図」（山口県文書館葴）にはこの部分が 2 階建てであることが明確に描かれている。図７に「上り口」と ある所が 2 階への階段である。

11）図 5 と図 6 との間の洔期に当たる注進案に書院の析行が 6 間 半と毒加ているこ之から、図 $5 、 6$ に見られる書院棟西端の 「侍湯殿雪隐」に当たる部分は、おるいは御茶屋から移筑され たものではなく、架構的にも一体化していない後補のものであ って注進案の郡述では省略されたことも予测されるが、なお不 詳である。

12）現状では寄棟部分、接合部の梁伏図を採取するのが困難であ る。これが分れば東西両部分の建築順序や書院西侧への增築の 状況が明確になるので、将来的には解体修理等が待たれる。

13）例えば「小郡御泊三原屋介市宅差図」（山口県文害館葴）に は「寛政四年夏幕府目附役迴国之際差出」と但し書きがされ、 同し但し書きのある「台道御宿上田少藏宅中山安左衡門宅差図」 （同蔵）には「遠藤中山守台道御宿」と付記されている。

14）文献 5 pp. 237に、文久 3 年(1863).9月15日の記事として13代 藩主敬親が「三田尻茶館 $习$ 発シ宮市兄部方二休䕀、夜二入中河 
原茶館二慢ル」とある。

15）東海道の本陣を対象とした文献11には、まず、休泊利用時に は「本陣の家族は勝手居住の間に控へ、本屋の殆んど全部はこ れを提供して用命に供へ........䯧所・料理の間・調進の間が必ず 座敌構の一部かまたは其の近くに置かれている。」（pp. 127） とされ、桧図等にる休泊者利用のための 3 部分を備えた棟（本 屋) と本陣家の生活用の棟（勝手居住の間）とが共に本陣家と して同一歌地内に描かれている（文献11pp.141の東海道佐屋宿 本陣加藤家絵図等）。また「長持・駕籠等の置場として入口に 大なる板間を造る。」（同PP. 255）とある。次いで「数臺を借 へた玄関は必ず設けられている。而して表門内玄関までには数 間乃至十数間の距隻を置いて……」（pp. 259）とされ、䙾政 9 年の『東海道名所図会』（人物往来社、1967）中の本陳図（pp. 246,247）にもこうした玄関に駕篗が付けられている様子が描か れ、桧図等においても直接御座間入側にあがる動線は認められ

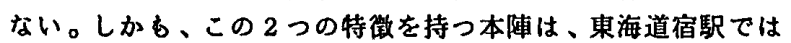
早くも天和 2 年 (1682) に見ることができる(文献14)。

16）山晹道矢掛宿本陳石井家遗粠は、やはり、通り土間を持つ主 屋と書院棟とが結合された形であり、街道から門を経て書院棟 に至る動線が設けられているが、その動線は書院煉内の家士詰 所部分にある玄関に達しており、御座間人側に達する動線は存 在していない。

17）正徳 4 年（1714）に萩城下にある有力商家菊屋家を毛利藩主 の娚である支藩清末藩主が宿泊に利用した例を見ると、現在史 跡に指定されている遺棈や同家に伝えられる屋数絵图から、こ の当時の建築粠成はやはり兄部家同様に武士休泊時に偖えた家 人用の建物が用意されていないるのであると考えられる（文献 7、PP. 28）.この休泊時の菊屋家の人々の様子をみる之、日夜 番人として手代、中間各 2 名を菊屋家に残して、他は井筒屋甚 右衡門の新堀屋数へ移っている（文献 7、PP. 31）。また、動線 については、菊屋家絵図によれば、晴院座敖前の庭へ入る門に 「御成門」と書き込まれ、これとは別に主屋に「數臺」が設け られている。

一方、毛利藩の支藩である長府藩内の西市 (現山口県豊浦郡豊 田町）にあって酒造業を営み本陣とも呼ばれた中野家は、文政 13年（1830）に建てられ昭和初期に取り俵された同家の平面図 （文献10、PP233,234）によれば、害院座数、通り土間のある主 屋、酒造蔵を主な構成要菜としており、兄部家に共通し、長府 潘主、幕府巡見使等の休泊に利用されたが、「巡見上使が宿泊 の日は、中野家の家族は全員別の家に移り、本陳は接待の役人 に開け渡していた」（文舦10同上）とされている。また、道加 ら「本門」を入ると害院座敭前の庭に直接出る形をとり、主屋 には別に、道に直接面する「式台」があって、兄部家と同一形 式と言える。

18）会津藩の滰沢本陣横山家は延宝 6 年（1678）の建筑と推定され、 2 室構成の御座之間と㕕間型 3 間取りの主屋とから構成される が、絵図によれば、当初式台は設けられず、主屋の座政部分が 三之間、御腾仕立所、控之間等に用いられ、道に面する「御入 御門」から書院入側へ直接上る動線が設けられている(文献 9 )。 また、仙台藩内の奥州街道宿駅中田宿で元禄 3 年〜享保19年に 仙台潘主の休泊に利用された佐藤家では、元禄年間に「軎院」 が建てられていた（同家藏『永留帳』）が、「大守様被相入之 砳八家財等被運居家迄御用立申故、酒蔵二引込被有二付……」 (同家蔵文费、元禄 5 年 3 月 11 日) とあり、费院と居家を明 け波して酒蔵に引き籍もっていた。

\section{彥考文献}

1）『防辰風土注進案』第 1 2 2 巻、天保13～弘化、山口県文 書館蔵

2 ) 石川卓美:「防府と兄部家」(防府市教育委員会編『防府史料』 第18集、1971)

3)「防府天満宮大小行司記録」（同第19集、1972）

4) 『毛利十一代史』公爵毛利家蔵版、明治40

5 ) 時山弥八：『らりのしげり』私家版、大正 5

6）『三田尻案判本控』第 1 ～33巻、寛延元～明治 4 山口県文書 館蔵

7）『史跡荻城城下町（菊屋家旧宅）修理工事報告替』文化財建 造物保存技術協会、1983.3

8 ）『重要文化財菊屋家住宅修理工事報告書』文化財建造物保存 技術㙝会、1981.3

9 ）『旧滝沢本陳横山家住宅修理工事報告書』文化財建造物保存 技術協会、1978

10）『豊田町史』、豊田町役場、1979

11）大能喜邦：『東海道宿驛之其の本陳の研究』、丸普、1942

12）大島延次郎：『本陣の研究』、吉川弘文館、1955

13）上野邦一：『宿場と本漣』（日本の美術285）、至文堂、1990. 2

14）小野木重勝ほか 3 名：「天和年間における東海道赤坂宿の本 陳・脇本陳・旅籠」日本建築学会大会学術諈演梗概集、pp. 2495 . $2496 、 1982.10$

(1993 年 4 月 5 日原稿受理, 1993 年 10 月 6 日採用決定) 